\title{
The Opportunities for Resolve the Certification Problem for E-Commerce Application in Albania
}

\author{
PhD candidate: Shqiponjë Açka \\ Lecturer of accounting in University "A. Xhuvani", Elbasan, Albania \\ ackashqiponja@yahoo.com
}

\section{Doi:10.5901/mjss.2014.v5n10p696}

\section{Abstract}

\begin{abstract}
The purpose of this paper is to study the ways in which can be made possible certification of virtual pages created by Albanian companies in order to realize electronic commerce. The main reason for this certification is to be increased the trust level of buyers' participants in virtual trade model. Foreign studies show that the security of virtual buyers is an important factor in the success of electronic commerce. Based on the conclusions of these studies, for businesses that tend to apply electronic commerce by Albania in this paper we presented three possible options of certification for resolving the current problem of this model trade: - Certification from international organizations specialized in trust services. - Selling products into space purchased in virtual shops of certified companies. - Use of personal privacy agreement. To provide conclusions based on buyers perceptions regarding to the level of trust offered by each alternative, in this paper I will also realize a questionnaire addressed to the Albanian virtual buyers. Taking in consideration their perceptions we will realized one analyze through the use of statistical methods. This analyze will help me to draw the conclusions of this study. In order to provide more clear conclusions in this research, I will study only the certification of electronic commerce for increasing trust and will not been included in paper other factors that may affect the success of a virtual model of trade.
\end{abstract}

Keywords: E-commerce, trust services, Albanian registered accounting experts, Albanian virtual buyers

\section{Introduction}

\subsection{Situation of e-commerce application in Albania}

The increase of the number of computer technology and the internet's users attempt the added premise application of electronic commerce by businesses operating in Albania. Initially, the first companies in Albania who attempted to create their web pages used it only for advertising the company itself and the products they offer. Many websites continue also yet to have this feature.

First companies that started using websites to make sales were virtual tour companies. Significant is the fact that even today the only company to continue to realize sales through internet belong to this sector. Many buyers in this market remain largely foreigners and Albanians ${ }^{1}$ tend to buy travel tickets through the internet and it seems like ever increasing in number compared to the first years of using this model.

Another sector which attempted to develop by applying virtual sales sector in Albania is also selling used cars. Most of these pages were opened just as informative site but some later returned to the merchant site. Unlike travel companies, which were businesses, virtual market sales of vehicles are used primarily by individuals belonging to unregistered businesses. Because of low reliability and lack of security, number of buyers in these pages was found to be almost zero ${ }^{2}$. This prompted them to return back to the origin, like the site simply informational and advertising.

Currently there is a tendency of some Albanian companies ${ }^{3}$ which use their web sites not only for information but also provide the opportunity for virtual sale of their products. Also for individuals, sites such as Ebay, amazon.com, etc., have created the opportunity to become part of the virtual world markets through the sale of personal products in these pages versus a commission.

\footnotetext{
${ }^{1}$ Besides the lack of confidence also the high numbers of ticket agencies in Albania cause this situation. It has often unnecessary use of virtual pages for purchase.

${ }^{2}$ But there is no official evidence and from unofficial information has been confirmed that the number is zero.

${ }^{3}$ Mention here such as www.shtepiaelibrit.com site, www.albaniancorner.com, www.123albania.com, etc.
} 


\section{Trust services in Albanian economy}

From several years now electronic commerce is a commercial model known from Albanian companies and individuals. But the facts show that websites created to realize electronic commerce by companies or individuals in Albania does not contain any of the trust seals for certificate these services ${ }^{4}$. Absence of certification of websites is considered as one of the reasons why Albanian internet sites are considered unsafe ${ }^{5}$ to conduct virtual trade.

In the current situation in Albania audit services provided by auditors are not perceived in the importance that they should have really. From the major part of Albanian companies audit services are contracted simply because they have legal obligations to make possible the implementation of certain procedures. For the reason that security services currently are not covered by the Albanian legislation, these services are almost unknown in Albania.

However, in the manner that the electronic commerce becomes applicable and successful in Albania, as much as is known, it is necessary to be studied how trust services can be provided with competence and quality.

\section{The position of trust services in training period of Chartered Accountants Registered in Albania}

\subsection{Knowledge training of Chartered Accountants Registered in Albania during the internship}

Until April 2013, the number of Chartered Accountants Registered in Albania was $200^{6}$ experts. To be licensed as a certified public accountant, according to Albanian law, candidates must attend a mandatory internship period at a vocational expert. During this period, which lasts $3-5$ years ${ }^{7}$, candidates must also make annual mandatory training and are tested on the knowledge gained during the training. Knowledge training during the internship includes:

- Knowledge of accounting and financial reporting GAAP

- Knowledge of accounting and financial reporting according to IAS / IFRS

- Audit of Financial Statements prepared for general use

Each of these modules includes 40 hours of mandatory training.

3.2 Comparison of knowledge required for the provision of trust services and knowledge that get Albanian public accountants in mandatory training

The following table reflects the knowledge needed to take the title for the provision of trust services for electronic commerce $^{8}$, the knowledge that are needed to be certified as an expert accountancy registered in Albania and training that have make Albanian auditors for 2013. The goal is to study how Albanian experts are able to provide trust services competently.

\footnotetext{
${ }^{4}$ Webtrust or Systrust

${ }^{5}$ This is more reason for foreigners who recognize the trust services and know how to check the validity of the trust seal and opinions of auditor expressed in the report of the engagement. In Albania only a very small fraction of individuals recognize the trust services and guarantee that they offer.

${ }^{6}$ www.ieka.gov.al

7 This period depends on the form of commitment, service contract or contract of employment.

${ }^{8}$ These are tests that must be passed to be certified as a specialist in the U.S. for providing trust services.
} 
Table 2.1: Comparison of knowledge needed for trust services and knowledge that get Albanian public accountants in mandatory training

\begin{tabular}{|c|c|c|}
\hline $\begin{array}{l}\text { Testation for certification } \\
\text { for trust services }\end{array}$ & $\begin{array}{l}\text { Tests to become certified public accountant } \\
\text { registered in Albania }\end{array}$ & $\begin{array}{l}\text { Areas of training of public accountants } \\
\text { registered in Albania in } 2013\end{array}$ \\
\hline $\begin{array}{ll}\text { Sectioni } & 1- \\
\text { assessment }\end{array}$ & $\begin{array}{l}\text { Exam } 1 \\
\text { Accounting, financial reporting and analysis of } \\
\text { financial } \\
\text {-Financial Accounting } \\
\text {-Cost Accounting and management } \\
\text {-Analysis of Financial Statements }\end{array}$ & $\begin{array}{l}\text { Updates with changes in tax } \\
\text { legislation in the Republic of } \\
\text { Albania } \\
\text { - VAT, Income tax, excise, } \\
\text { etc. }\end{array}$ \\
\hline $\begin{array}{l}\text { Section } 2 \text { - Considerations } \\
\text { for fraud }\end{array}$ & $\begin{array}{l}\text { Exam } 2 \\
\text { The civil law, criminal code, business legislation and } \\
\text { code of work in Albania. } \\
\text {-The civil rights - civil code and code of civil } \\
\text { procedure } \\
\text {-Business Legislation } \\
\text {-Criminal Legislation - criminal code and code of } \\
\text { criminal procedure } \\
\text { - Labor legislation - Labor Code and the Law on } \\
\text { Health Insurance } \\
\text {-Bankruptcy Law } \\
\text {-Prevention of money laundering and terrorist } \\
\text { financing }\end{array}$ & $\begin{array}{l}\text { Legal treatment of the merger, separation and } \\
\text { absorption of the business entity }\end{array}$ \\
\hline $\begin{array}{l}\text { Section } 3 \text { - Internal control } \\
\text { and total control of } \\
\text { information technology }\end{array}$ & $\begin{array}{l}\text { Exam } 3 \\
\text { Code of ethics for professional accountants and } \\
\text { standards on specific concerns } \\
\text {-The organization of the profession of Chartered } \\
\text { Registered Accountants } \\
\text {-Professional Ethics } \\
\text {-Conduct of audit in accordance with international } \\
\text { auditing standards } \\
\text {-Professional Standards to implement other security } \\
\text { commitments, review and other similar } \\
\text { commitments but different from the audit of financial } \\
\text { statements } \\
\text { for general use. }\end{array}$ & $\begin{array}{l}\text { Procedures to be followed in } \\
\text { case of bankruptcy of the } \\
\text { companies }\end{array}$ \\
\hline $\begin{array}{l}\text { Section } 4 \text { - Evaluation, } \\
\text { Testing and Reporting }\end{array}$ & $\begin{array}{l}\text { Exam } 4 \\
\text { Organization, management, } \\
\text { administration and internal control of the business, } \\
\text { including information systems and computing } \\
\text {-Basic principles of organization and management } \\
\text { of business } \\
\text {-Information Systems } \\
\text {-Internal controls, components and its organization } \\
\text {-Administration of the business, the role of the Code } \\
\text { of Good Governance. }\end{array}$ & $\begin{array}{l}\text { Consolidation accounting treatment in the } \\
\text { financial statements prepared under IFRS and } \\
\text { NAS }\end{array}$ \\
\hline $\begin{array}{l}\text { Section 5 - Information } \\
\text { Management } \quad \text { and } \\
\text { Business Intelligence }\end{array}$ & $\begin{array}{l}\text { Exam } \\
\text { Fiscal legislation in the Republic of Albania } \\
\text { - Administration of the fiscal obligations in the } \\
\text { Republic of Albania, the procedures followed for the } \\
\text { collection of taxes. Tax structure. Authorities } \\
\text { responsible for taxes at the national and local level } \\
\text { - Personal Income Tax } \\
\text { - Value added tax } \\
\text { - Local Taxes } \\
\text { - Excise and Customs duties } \\
\text { - Social security and health }\end{array}$ & $\begin{array}{l}\text { Expected improvements in National Accounting } \\
\text { Standards in the Republic } \\
\text { of Albania } \\
\text { Determining Materiality in Audit of Financial } \\
\text { Statements }\end{array}$ \\
\hline
\end{tabular}


So, obviously, candidates registered for auditors aren't tested in their mandatory training and testing outsourcing for information technology knowledge. Only examination of the third and fourth testing included knowledge of trust services and information technology but the significance of these findings occupies only $10 \%$ of the total points ${ }^{9}$. While mandatory training included no knowledge on information technology training but the training are based on the application of standards for specific aspects, to audit the financial statements for general use as well as to recommendations for improvements to be made to legislation fiscal.

In conclusion, based on the knowledge gained in training, we can say that: not only companies but also auditors do not recognize Albanian trust services and currently aren't trained for providing these services with competence and quality ${ }^{10}$.

\section{Possibilities of resolving the problem of virtual trade certification offered by businesses in Albania}

Virtual pages of companies that implemented electronic commerce from Albania are not equipped with the security seal ${ }^{11}$ to be certified as reliable company for customers. Lack of certification by a credible authority creates difficulty for these companies often bringing into bankruptcy and closure of the site or its use only to provide information to buyers.

To ensure customer confidence, companies that tent to apply electronic commerce from Albania have some alternatives:

\subsection{To be certified in international programs offered by international organizations}

Every company, regardless of geographic location, has the right to apply to a program of certification for virtual trade offered from international organizations. If companies operating in Albania aim to be certified by international programs, they can apply to be equipped with one of the seals: VeriSign, CPA WebTrust, TRUSTe, BBBOnline or TruSecure. If we compare the costs of the application on each of these programs, the situation is as follows:

Table 3.1: Costs of issuing trust seals from international organizations

\begin{tabular}{cccccc}
\hline $\begin{array}{c}\text { Trust seal } \\
\text { Costs }\end{array}$ & VeriSign & CPA WebTrust & TRUSTe & BBBOnline & TruSecure \\
\cline { 1 - 5 } & $1000000 \$-1500000 \$$ Variable annual commission & Over of $8000 \$$ & $299 \$-6999 \$$ & $150 \$-3000 \$$ & Over of $40000 \$$ \\
\hline
\end{tabular}

As the table shows, the costs of involvement in international certification programs are high for companies operating in Albania. However, financial condition remains not the only obstacle. Also, companies must meet a variety of other conditions related to safety before to join these programs.

Given the orientation of companies operating in Albania to lower costs as in the software selection as well as selection of computer equipment needed, we conclude that only a very small number of these companies can be qualified for certification with security seal.

However, within this alternative exists another option for companies that implement electronic commerce from Albania: equipped with security seals issued by the Albanian accountancy specialists ${ }^{12}$. Actually we haven't Albanian accounting specialists certified to provide trust services for electronic commerce but this could be a great opportunity for younger generations of accounting experts. Younger accounting experts who are equipped with the best knowledge for technology information, some of whom work in foreign subsidiaries auditing companies that operate in Albania, can undergo testing to obtain a license by AICPA or CICA and get experience to the parent auditing companies ${ }^{13}$. This could be a great opportunity not only to take the CPA WebTrust service at a cost affordable by companies in Albania but also to

\footnotetext{
${ }^{9}$ www.ieka.gov.al

${ }^{10}$ The same perception exists among people asked who the greatest number of them assesses Albanian auditors in the level 1-2, so no or few actually competent to provide trust services for electronic commerce.

${ }^{11}$ Actually deemed reliable site to purchase virtually only a few pages created from well-known companies which apply the traditional model of trade along the virtual model. Also a reality that is becoming more and more popular in Albania is the use of official web sites of some well-known companies like Ebay or Amazon.com but also 123albania.com, the site in which companies or individuals may reserve space for sales versus a commission.

12 These specialists will be certified to provide trust services for electronic commerce by international institutions according to criteria set by them.

${ }^{13}$ These companies like Ernst \& Yang, KPMG etc., in other countries provide trust services through licensed professionals employed by them.
} 
increase the number of services and revenue for Albanian accounting experts.

\subsection{To function by conducting electronic commerce on the official websites of known companies}

The realization of electronic commerce in this form can't allow Albanian companies to create their own webpage, but they will be forced to sell in the sites of known companies since their credibility and prestige is guaranteed by their name. Costs of implementation of electronic commerce through this alternative are known and published ${ }^{14}$. However, one of the biggest benefits of the implementation of trade under this alternative is the fact that actual and potential buyers in these pages are numerous ${ }^{15}$. While the biggest difficulty for companies that want to implement electronic commerce via this method is to create a personal image and reputation which directly affect the success of their initiative.

\subsection{Establish agreements preserving personal privacy}

Companies operating in Albania and want to become part of the virtual market but can not afford the financial cost of the security seal, are able to ensure the trust through the development of privacy agreements. One such example is the case of amazon.com, company that guarantees security for virtual buyers through personal agreement.

However, although this option can be considered as alternative with less financial cost, it is not successful for all companies. Privacy agreements can be trusted by buyers when they are provided by virtual well-known company and reputable in the business. For this reason, if this option is chosen and will be applied by the unknown company the risk of failure of their initiative would be too high.

\section{Criterion of signs to determine the best alternative to solving the problem of certification under perceptions of Albanian virtual customer}

To determine which of the alternatives mentioned in the above case, in terms of problem solving certification websites where electronic commerce is realized, is more reliable and urges more Albanian potential buyers to make real purchases in Albanian virtual companies we have tested criteria used Cruscal - Wallis analyze. Reasons for selection of this statistical method are:

$\checkmark$ Information that is used to test belongs to a nominal level and it does not allow us to use parametric methods for testing.

$\checkmark$ The study has three alternative choices for analysis which are considered three different populations

$\checkmark$ Each of the respondents has the right to respond to the perceived level of trust for each option

Hypotheses rose in this part of the paper which will be tested through the use of Cruscal -Wallis criterion is:

Ha: Three alternatives for guaranteeing trust in the virtual pages of Albanian companies not affect the perception of the same level of security to Albanian virtual buyers

Assumptions relevant for this study are:

$\checkmark$ Distribution of data is assumed to be normally distributed.

$\checkmark$ The error margin allowed in this study was $a=0.05(5 \%)$

To prove the hypothesis rose in this study according to the ranking criterion Cruscal - Wallis is necessary to be calculated two statistics, factual and theoretical. Since in the study we have three populations the statistics that will be used is $\times 2$ statistics.

The formulas used for finding statistics are as follows:

$$
\begin{gathered}
W=\frac{12}{\mathrm{nt}(\mathrm{nt}+1)} \sum \frac{\mathrm{Ri} 2}{\mathrm{ni}}-3(\mathrm{nt}+1) \\
X^{2}=X^{2} 0.05(\mathrm{k}-1)=\chi^{2} .05(3-1)=5.99 \mathrm{~d} . \mathrm{s}
\end{gathered}
$$

\footnotetext{
${ }^{14}$ Companies like Ebay and Amazon.com have published on their official websites the commissions that have to pay individuals or companies who want to use these websites to make sales.

${ }^{15}$ The main aim of clicking from individuals and companies in these pages is not participating in trade but simply the device with the latest information.
} 
Results of the study after replacing indicators in the formula are:

\begin{tabular}{|c|}
\hline $\begin{array}{c}W=217.58 \mathrm{~s} . d \\
X^{2}=5.99 \mathrm{~s} . d\end{array}$ \\
\hline $\begin{array}{l}\text { Where: } \\
\text { W-factual statistics } \\
X^{2} \text { - Theoretical Statistics } \\
n_{t} \text { - number of total respondents } \\
R i^{2} \text { - the ranks of each population } \\
n_{i} \text { - number of respondents for each level of education }\end{array}$ \\
\hline
\end{tabular}

Based on the results we can say that, since $W>x 2$, Ha hypotheses raised in the above is verified. So, as a conclusion we can say that Albanian virtual buyers have different perceptions regarding the guarantee that each of the trust alternatives offers. Also, if we look at the distribution of data regarding the perceived of guarantee by Albanian virtual buyers, we conclude that the alternative of certification of virtual pages in international companies is the alternative which offers more security. Alternative of use by Albanian virtual companies of popular websites also creates an acceptable level of trust while is perceived low level of security if the companies would use privacy agreements to ensure trust. Personal privacy agreements are quite used by foreign companies but aren't perceived trusted from Albanian virtual buyers. The main reasons are:

- Albanian fiscal legislation for virtual companies doesn't exist and therefore personal privacy agreements will not provide any warranty in the conditions of controls absence

- Virtual companies operating in Albania currently aren't enrolled in any public institution operating in conditions of complete anonymity. This affects the invalidity of privacy agreements created by the virtual company.

However, in this study is noted that there are differences in terms of perceived security option as most trusted by Albanian buyers. For this reason, we think that the education level of respondents may have influenced the creation of these differences and to test statistically this trial we used statistical method of independence criterion to determine whether or not affects the respondents ' education level in their perception of trust.

Hypothesis raised is:

\section{Ha: Alternative perceived like more trusted depends on the education level of the respondents}

The survey data are interval scale and is therefore acceptable use of a parametric method such as the method of control hypothesis based on the criterion of independence ${ }^{16}$. To follow control procedures in order to establish hypotheses rose above shall be calculated values of two control statistics, statistics theoretical and factual statistics. Statistics used in this statistical model is $\times 2$ statistics (Chi-square).

The formulas used by this method for finding the control statistics are:

$$
\begin{gathered}
\chi 2 \text { factual }=\sum_{i}^{n} \sum_{\mathrm{j}}^{\mathrm{m}} \frac{(\mathrm{fij}-\mathrm{pij}) 2}{\mathrm{pij}} \\
\chi^{2} \text { theoretical }=X^{2} 0,05(n-1)(m-1)=\chi^{2} 0,05(3-1)(3-1)=9.49 \text { s.d }
\end{gathered}
$$

Results of the study after replacing indices in formulas are as follows:

\footnotetext{
${ }^{16}$ Regardless of the study are only 203 valid questionnaires, the total number of units is 224, equal to the number of responses at 5 level of trust perceived by buyers. This is because 15 of the respondents did not respond to level 5 for any of the trust options while 36 others are also responding to level 5 for two alternatives. In the first group of 15 persons who did not respond with any alternative at 5 level simultaneously, 9 have higher education and 6 secondary education. While in the second group 22 persons with higher education, 9 with secondary education, and 5 with lower educational level than secondary education have rated level 5 for both alternatives simultaneously. Also, we chose to study only the scale responds with 5 safety evaluations since it is a higher degree of perceived guarantee by the buyer and the level of guarantee can turn them from potential buyers in real buyer in websites of Albanian virtual companies.
} 
Were,

$X^{2}$ factual $=40.91$ d.s.

$X^{2}$ theoretical $=9.49 \mathrm{~d} . \mathrm{s}$

$\alpha=0.05$,

$n$ - number of categories of the variable security option

$m$-number of categories of the variable level of education

Fij-factual density of the questionnaires

pij-calculated expected density

Based on the results of the study we can say that, because $x 2$ factual $>x 2$ theoretical, hypothesis raised in the study is verified. Thus, respondents' education level affects the perception that they have regarding the guarantee that each of the alternatives offers. The data show that lowering the level of education increases the number of people who perceive that trust must be guaranteed by foreign professional bodies. Those respondents with higher education have an almost equal split in terms of perceived trust from international professional bodies as well as the use of known websites to carry trade. Interest reflects the fact that we have a high percentage (approximately $21 \%$ ) of people who have a lower education level than secondary education to perceive that personal privacy agreements can be a guarantor of trust for Albanian virtual companies. A possible explanation of this outcome is the reason that this part of the study's population fails to perceive the real meaning of the term privacy agreement ${ }^{17}$.

\section{Conclusions}

Statistical data associated with the application of electronic commerce by businesses in Albania are scarce. This conclusion also is accepted by studies carried out by INSTAT ${ }^{18}$, which determines that it is necessary to be registered businesses that apply electronic commerce from Albania in order to have full and official statistics.

In the current conditions in Albania although that are performing their activities more accountants and auditors we conclude that trust services can not be provided with competence. This conclusion is based on the fact that accountants and auditors in Albania did not undergo training on information technology and trust services. For this reason, businesses that implement electronic commerce from Albania must find other ways to certify websites and computer programs that are used for virtual trading and can not contract Albanian experts.

Option that provides more security for Albanian virtual buyers to participate in electronic commerce conducted by Albania is certification websites from companies or international institutions specialized for trust services. We deem that this is the right option in Albanian economic environment where uncertainty is high and buyers.

\section{References}

AICPA, 2013, Service Organization Controls. Managing Risks by Obtaining a Service Auditor's Report

Clinton E. White, Internet Transaction Anxiety \& Recognition of Assurance Services The International Journal of Digital Accounting Research, Vol. 1, No 1, pp. 25-45, ISSN: 1577-8517

Corbitt, B.J, Thanasankit, Th. \& Yi, H. (2003). Trust and e-commerce: a study of consumer perceptions, Electronic Commerce Research and Applications 2 (2003) 203-215

Daly, B. A., and D. K. Schuler. 1998. Redefining a certified public accounting firm. Accounting, Organizations and Society 23 (5/6): 549567.

Fogarty, T. J., and V. S. Radcliffe. 1999. Extending practice: accountants' constructions of the industrial relations arena in the USA. Accounting, Auditing \& Accountability Journal 12 (5): 525-560.

Haavelmo, T.1943. "The Statistical Implications of a System of Simultaneous Equations." Econometrica 11:1-12.

http://www.amazon.com

http://www.bbbonline.com.

http://www.cpawebtrust.org.

http://www.truste.org

Mauldin, E. and Arunachalam, V. (2002). An experimental examination of alternative forms of Web assurance for business-to-consumer e-commerce. Journal of Information Systems, 16(1), 33-54.

www.ieka.gov.al

${ }_{17}$ Before completing the survey asked people aren't take detailed information regarding the meaning of terms.

${ }^{18}$ Albanian Institution of Statistics 
www.truesecure.com/

www.verisign.com

\section{Appendix: Questionnaire}

1- What is your educational level?
a) High
b) Medium
c) lower than the medium

2- Do you make virtual purchases in Albanian website' companies?
a) Yes
b) No

3- Do you think that websites of Albanian virtual are safe?
a) Yes
b) No

4- On a scale of $1-5$, determine the perceived level of your trust regarding the three alternatives that guarantee security in electronic commerce.

\begin{tabular}{|c|c|c|c|c|c|}
\hline & 1 & 2 & 3 & 4 & 5 \\
\hline Certification from international organizations specialized in trust services & & & & & \\
\hline Selling products into space purchased in virtual shops of certified companies & & & & & \\
\hline Use of personal privacy agreement & & & & & \\
\hline
\end{tabular}

5- What is the reason for this perception? Specify

Thank You! 
This journal is printed for MCSER

By Mediagraf SPA

Via Leonardo da Vinci, 8, (RM)

Telefono: +390643560502

Fax: +390643534468

E-Mail:info.rm@mediagrafspa.it 